This item was submitted to Loughborough's Research Repository by the author.

Items in Figshare are protected by copyright, with all rights reserved, unless otherwise indicated.

\title{
Governance learning: building a network around managerial innovations
}

PLEASE CITE THE PUBLISHED VERSION

http://dx.doi.org/10.1108/S2051-663020150000004010

\section{PUBLISHER}

(c) Emerald Group Publishing

\section{VERSION}

AM (Accepted Manuscript)

\section{PUBLISHER STATEMENT}

This work is made available according to the conditions of the Creative Commons Attribution-NonCommercialNoDerivatives 4.0 International (CC BY-NC-ND 4.0) licence. Full details of this licence are available at: https://creativecommons.org/licenses/by-nc-nd/4.0/

\section{LICENCE}

CC BY-NC-ND 4.0

\section{REPOSITORY RECORD}

Vitry, Chloe, and Eduardo Chia. 2019. "Governance Learning: Building a Network Around Managerial Innovations". figshare. https://hdl.handle.net/2134/23546. 


\section{GOVERNANCE LEARNING: BUILDING A NETWORK AROUND MANAGERIAL INNOVATIONS}

\section{Authors}

1. Chloé Vitry (corresponding author), School of Business and Economics, Loughborough University.

Affiliated with UMR Innovation.

Bât 27,

2 Place Pierre Viala

34060 Montpellier Cedex 02

France

chloe.vitry@gmail.com

2. Eduardo Chia, INRA - SAD, UMR Innovation,

Bât 27,

2 Place Pierre Viala

34060 Montpellier Cedex 02

France

chia@supagro.inra.fr

Chloé Vitry has a PhD in Management, recently graduated from Montpellier SupAgro. Her thesis focused on the learning processes in governance mechanisms in periurban territories, in France and Morocco, with a strong focus on a critical approach to managerial instruments. She is currently working as a Research Assistant at the University of Loughborough, School of Business and Economics, on an ESRC funded project studying the diffusion of technical innovations in the house-building industry.

Eduardo Chia is a research director at INRA (French National research institute for agriculture), UMR Innovation, where he conducts research of governance mechanisms, the role of instruments and governance apparatus, and learning. He has a strong experience in studying agriculture in Europe, Africa and Latin-America, where he worked on rural development. 


\title{
GOVERNANCE LEARNING: BUILDING A NETWORK AROUND MANAGERIAL INNOVATIONS
}

\begin{abstract}
Purpose

Actors of territories faced with new managerial innovations have to develop new knowledge and behaviours to seize these innovations and create a vision of the territory. This is part of what we call governance learning: the ability of individuals to create new knowledge and behaviour for collective action within the territory. The purpose of this paper is to explore this concept.

\section{Design/methodology/approach}

Drawing from a case study of a periurban territory in France, we analyse how the board members of a Community of Communes can learn to work together, articulating organisational learning theories, actor-network theory, and the concept of organisational myths.
\end{abstract}

\section{Findings}

We explore the enrolment process necessary to "build" the network and interest them in using the innovation; identify three types of governance learning that turn the network into a collective: sensemaking, instrument-seizing, and sensegiving; show how these myths are necessary to turn collective knowledge into organisational knowledge.

\section{Research limitations/implications}

With both a behavioural and evolutionary approach to governance, we show that power, relationships and learning processes are tightly intertwined within the governance networks. Our use of organisational learning theory also demonstrates how it can be used in a more systematic way to describe the learning processes witnessed in governance situations.

\section{Practical implications}

This research brings new light to the understanding of how territorial governance can be developed and how managerial innovations can provoke learning situations, and more specifically how stakeholders learn to define common goals and a shared vision of their territory to enable collective action.

\section{Keywords}

Organisational learning; territorial governance; actor-network theory; managerial instruments; organisational myths 


\section{INTRODUCTION}

The notion of governance has been increasingly more popular, both in research and practice. It is both a managerial method (corporate governance) and public action method (public governance, territorial governance). Rhodes identifies as many as six different definitions of governance (Rhodes, 1997). In contrast with the notion of corporate governance imported to the New Public Management, it is the one integrating the notion of network governance that we find the most relevant. In it, governance is seen as a weaving of more or less stable social relationships between mutually dependant stakeholders, organised around complex political issues.

\section{Territorial governance in France}

In France, the removal of the State from public affairs in favour of local branches was organised through a decentralisation policy (loi 1982). State/region contracts (contrats de plan Etat/Région), inter-municipal charters (chartes intercommunales), province contracts (contrats de pays) are examples of the many apparatus designed for land settlement, at an increasingly high diversity of scales.

The coming of the European Union as a new public figure and its implication in sub-national levels (as illustrated by the European policy for regional development) added supra-national levels to this weft. The increase in number and complexity of exchanges gave birth to what is today called multi-scale governance. It both refers to the relationship between a diversity of stakeholders ${ }^{1}$ (public stakeholders, citizens, NGOs, private organisations, etc.) and a diversity of scales (municipality, region, State, European Union). Apparatus are then designed to help shape the relationship between these two dimensions. Among all these levels of governance, it is the "lowest", the local level, which is of interest to us: because it is observable, the exchanges between stakeholders focus on issues anchored in space, and the stakeholders are often physically represented in the territory.

It is through this decentralisation process that local governments (municipalities, départements, regions) gain means and power to organise and develop their own territory. When it was before organised by state services divided in sectors, local public affairs are now the responsibility of local elected officials and employees of the local government. To help them in their task, experts (either private, through contracts; or public, from public offices) are often called in. The private sector (private organisations, citizens, associations, ...) also takes part in this process, both to claim its right to be heard and to participate in local matters, but also as experts in using : stakeholders who, through their use of the territory, know its challenges, strengths and weaknesses and are closer to innovations and thus potential solutions (Callon et al., 2001). Herein lies the idea of participative governance: a way of managing local life, efficient because it includes a number and diversity of stakeholders.

The notion of the territory as the local level of governance stems from the idea of the local not being a simple division of the global, but rather a complex social construct (Leloup et al., 2005). Territorial governance is thus seen as a managerial tool in a complex environment. As such, each territory is unique, bound to a space and available resources, but also a social component. The territory is a coherent and constructed system, invested in by those who inhabit it, defined by their collective projects, their coordination and cooperation in situations of interdependency.

\footnotetext{
${ }^{1}$ We use the term stakeholder here in the broad sense of a person who has an interest in the situation. We do not refer to stakeholder theory as defined by some research in economics or management.
} 


\section{The SCOT: an instrument for public action}

To guide local governments in organizing their territories in accordance to governance ideals, the State has created a number of instruments for public action. In 2000, a national law passed in parliament to create such an instrument, the SCOT (Schéma de Cohérence Territoriale), a type of urban master plan to integrate policies at the level of inter-municipalities or higher. Its goals are, among others, to ensure the consistency of the municipal urban planning (Plan Local d'Urbanisme or PLU) of the perimeter it encompasses, and to plan the development of the territory in a sustainable fashion. It entails three documents: a diagnosis of the territory; a sustainable territory development plan, which sets the direction of the territory for the next 10 years; and a document of orientations, declining the development plan into tangible rules and actions. Integrating the principles of governance, the process under which the SCOT is created must include participatory approaches. Experts and other public services (representatives of the State, but also of the département) are also included, both to guide the council and to ensure respect of the law. As an instrument for public action, the SCOT requires new knowledge, and thus learning (Danet, 2010).

Coordination and cooperation between stakeholders in some territories are uncertain because of differences, conflicts of interests, prejudices, etc. This is the case especially of periurban territories. With growth and urbanization rates climbing higher and higher, cities are colonizing the country. The installation of new inhabitants in the rural villages in suburban housing and the proliferation of local services are transforming both the landscape and the ways in which rural cities operate (Rousier and Bertrand, 2003; Soulard and Thareau, 2009). This phenomenon, called periurbanisation, creates great strain in many ways. With the arrival of new inhabitants the prices of real estate skyrocket, both encouraging farmers to sell their land for great profit and making it more difficult for new farmers to acquire land, thus leading to the rarefaction of agricultural practices in these territories. The resilience of agri-urban systems (Perrin et al., 2013) is thus put to the test, and the ability to work collectively and cooperate is precisely one of the key components of this resilience (Adger, 2010). The arrival of new inhabitants also means that these territories are now the scene of a new need for cohabitation and collaboration between previous inhabitants and new ones(Torre et al., 2006). This particular strain is a strong characteristic of periurban territories.

This fast-growing phenomenon places the need for collective action at the centre of the debate, the challenge of involving strangers together motivating our research. The idea that people coming from different backgrounds, with different personal goals, a different language, a different culture, can collaborate to successfully develop a territorial strategy and project themselves in the future is a new challenge for periurban territories in general and our example in particular. Territorial governance in periurban territories can then be seen as the necessary tool allowing through consultation processes to circumvent differences, resolve conflicts, and avoid prejudices. But it is also put the test in this precise context. This is the two-fold challenge of territorial governance, both a tool and a stake in itself (BerrebiHoffmann and Boussard, 2005).

As a process of coordination between local actors with different goals, strategies and resources, territorial governance relies on instruments (SCOT, PLU, Territorial Contracts) and can create learning which will impact the sustainability of modes of governance. Our research question is then to understand how stakeholders in a periurban territory can learn to cooperate. In particular, how can the SCOT, an instrument for public action, create situations of governance that enable learning processes in the context of a fast-changing territory? 
In this paper we will first present or framework, in which we construct the notion of governance learning. Then we will present the case study and our general method. Our results will be presented through three approaches: Actor-Network Theory, Learning processes, and Organisational Myths. In conclusion we will develop the importance of learning processes on territorial governance.

\section{FRAMEWORK}

To understand the relationship between the SCOT and the opportunity of learning for governance, we construct a framework in three parts. First, we analyse the literature review to explore the idea of 'governance learning', building up to a definition of the term. Then we develop the notion of managerial innovations to illustrate the scientific interest of studying them in the context of learning processes. Finally, we propose the use of Actor-Network Theory to illustrate the relationship between managerial instruments, governance stakeholders and learning processes.

\section{From organisational learning to governance learning}

To understand how stakeholders can learn to cooperate in situations of governance, we made the assumption that the territory can be likened to an organisation, and so the mechanisms behind learning that are applicable in private organisations can also be applicable to the territory. Learning is a process of change that happens when people create new knowledge and/or change their behaviour. According to Argyris and Schön (Argyris and Schön, 1996), learning happens when people detect a discrepancy between what they think should be happening, and what is effectively happening. Learning is what happens when they adjust their behaviour to match the two. We think this can be expanded to any new situation that presents itself to the learner, even if they are able to assume what should be happening correctly at first attempt. In the tradition to constructivist scholars (Örtenbald, 2001), we categorise three distinct 'subjects' of learning: individual, when one learns alone; collective, when learning is produced in a group; and organisational, when learning is not embedded within the individuals who produced it, but embodied within organisational routines.

Argyris and Schön (op. cit.) offer a framework around two types of learning: first- and second-order. First-order learning refers to a change in strategy, whereas second-order learning refers to change in goals or the values that stir them. Other scholars have focused on the process of knowledge creation and transfer. Nonaka and Takeuchi (1997) in particular built a model of knowledge diffusion through four processes: externalisation (when implicit knowledge becomes explicit), combination (transfer of explicit knowledge from one learning entity to the other), socialisation (transfer of implicit knowledge from one entity to the other) and internalisation (when explicit knowledge is internalised by the entity).

The idea of learning in a context of governance is an emerging one. Many authors have started to investigate the relationship between organisational learning and governance. However, most of them tend to look at the way modes of governance can improve organisational learning and not how one can learn to create these modes (Berkes, 2009; Lamari, 2011; Newig et al., 2010; Rey-Valette et al., 2011; Young, 2010). Some authors do study the way in which organisational learning can enhance modes of governance. For example, what stakeholders learn during a consultation process can create a strong interest in following the process and participating later on (Innes and Booher, 2003). Newig et al. (op. cit.) also question the role of collective learning on the shape of governance networks. They say collective learning can produce an intensification of exchanges between stakeholders and thus a strengthening of the network. This can lead to more efficient communication in the 
future. Bruges and Smith present case studies in which situations of participative governance have been created to make the switch to sustainable farming practices. They note a lack of reproduction of these situations of governance, i.e. the absence of institutionalisation of governance (Bruges and Smith, 2007). The authors conclude there is a need for territory stakeholders to learn about governance practices (consultation, coordination, etc.) to institutionalise governance and turn it into a practice embedded into the territory, without which the switch to sustainability appears limited.

The purpose of this paper is to explore this possibility. Penning the idea of "governance learning”, we researched in the literature what could constitute its key components. Many authors have identified trust as a facilitating factor to share knowledge and experience (Sol et al., 2013). Others mention the importance of common goals to allow for collective learning (Van Assche et al., 2013). However, none talk about the creation of trust or the elaboration of common goals as a process that needs better understanding. A shared vision and shared mental models (Dieleman, 2013; Senge, 2006) are other key components. According to Senge, shared mental models are the internalized representations of the world that each of us possesses and which guide our actions. It is essential, according to Senge, for an organisation to become a learning organisation and a place of cooperation, that the people who constitute this organisation must learn to abandon their own private mental models to build this shared mental frame. Duguid et al. (Duguid et al., 2007) also mention the ability to communicate, cooperate and work in a team as key components of governance.

To us "governance learning" means learning to work together, but this entails much more: it means learning to share values, define collective goals, create a shared mental frame, learn a common language, and acquire organisational capabilities (take part in a meeting, speak in turns, vote, etc.). It is only when these essential components of governance have been learned that the network of stakeholders becomes a collective. Studying governance learning allowed us to build our own definition of the concept, as "the cognitive and behavioural processes allowing the territory's stakeholders to produce a shared vision of this territory, create a collective and develop it, and negotiate common strategy and goals".

Organizational learning is a process of change: change in behaviour, change in goals, and change in the way actions are perceived. But it is also a reaction to change: learning to adapt in new, uncertain situations. One of the ways in which stakeholders in a situation of change react is through the production of sensemaking (Weick et al., 2005). Sensemaking is the way people give sense or meaning to this process of change. Applied to the territory, processing this change is part of governance learning because it is when people find a reason for cooperation that they can start to actively learn how to cooperate. In a similar process to sensemaking, sensegiving is a way leaders supply a "workable interpretation to those who would be affected by [their] action” (Gioia and Chittipeddi, 1991).

\section{The managerial innovation}

According to LeRoy et al. (2013), "In its common use, innovation is associated with technology. It consists in producing an innovative product or process of production. This technological innovation is done in R\&D laboratories and can be measured by the number of patents the organisation holds". However, many authors agree to recognize other forms of innovations: institutional, organisational... and managerial, a notion introduced by Kimberly in 1981: "a managerial innovation is a program, a product or a technique perceived as new by the individual or the group considering its adoption and which affects the nature, quality and/or quantity of available information for decision taking within the organisation”. This definition is close to what Moisdon calls instruments. Later, LeRoy (op. cit.) defines a 
managerial innovation (MI) as: "the adoption, by an organisation, of practices and methods of management that are new to this organisation, with the goal to enhance its global performance". This definition covers two notions: MI as something new because it is created by the organisation, or because it is new in comparison with common practices within this organisation.

What interests us is the idea that MIs are necessary to trigger the learning processes which will allow stakeholders to build a common language, shared values, etc. (Chia and Napoleone, 2008). . According to Lascoumes and Simard (2011), it is through the study of these MIs that we can begin to understand these processes; not just through the analysis of actions and discourses of individuals but through the "materiality" of public actions. MIs are sometimes the origin of social and technical innovations driving this change (Berrebi-Hoffmann and Boussard, 2005). In short, they are not only the witnesses of change, the recipients of knowledge, they can also be a way to drive learning processes forward (Aggeri and Hatchuel, 1997; Moisdon, 2005). Individuals will seize these MIs and change them to fit their needs within the organization, which will produce learning, but the MIs in themselves will provoke change. A few terms can be used to designate managerial innovations, but some have nuances that are important. In this paper we will talk of three: tools, instruments, and dispositif.

According to Berrebi-Hoffmann and Boussard (op. cit.), the relationship between MIs and the organisation (or in our case, the territory) can be done in two ways: either by looking at the way the innovation changes the organisation (which among other things allows the study of organizational learning), or by studying the way the organisation changes the innovation. We think however that both aspects should be studied at the same time, because they are part of the same process, and we will show how this process can create synergies in our example. If managerial innovations produce learning (and change the organization), new knowledge must be in turn produced to learn how to use them, how to adapt them to a new situation, etc.

To analyse the diffusion and acceptation of MIs, we used Actor-Network Theory (ANT). Initiated by Callon, Latour, and Law, it allows us to analyse interactions between actors of a network based on the way this network is constructed through 'translation'. If successful, the result is to be "voices talking in unison and understanding each other" (Callon, 1986, p.204). This process of translation strongly resembles governance situations: construction of a network allowing actors with different identities and interests to cooperate to act collectively. Oiry (2003) develops the concepts of ANT to analyse construction and adoption of MIs within a network. He simplifies the theory, taking only the key concepts and applying them to the context of managerial innovations. He thus defines the process of translation of a managerial innovation as composed of three elements: the goal that an actor gives to this innovation, the role that this actor gives themselves so that the goal can be achieved, and the role they give to other actors of the network. The translation process goes through four phases: problematisation, creation of interessment devices, enrolment and mobilisation of allies. Another interesting concept of the ANT is that of "mediator", wherein an actor will set up interessment devices to interest and then enrol others and have them accept the role as defined both by the managerial innovation and the mediator.

\section{Organisational myths}

According to March, "myths allow members of a community to produce an interpretation of their environment on which they can rely, even despite their limitation to individually build from their own experience - useful representations and share them" (1999, p. 5). In the same manner, Hatchuel defines what he calls "rational myths" as limited conceptions of the world that allow collective action because they offer mental models (David, Hatchuel and Laufer, 
2001). Finally, Weick (1990) writes about “cartographic myths" as the "mental map” of relations, strategies, and representations that individuals create about their environment.

Organisational myths are thus produced to "encode" preconceptions and representations that people have about the environment in which they operate - in our case study, the territory. In time, as these myths become less relevant - or less cohesive with the changing reality as it is observed by the individuals, they are given up and new myths are built. In our case study, we will show how the situation created around the SCOT allowed the actors involved to produce such a myth: the "breathing space", which produced learning, and was then reinterpreted and internalised individually.

\section{RESEARCH METHOD}

\section{Case study}

To answer our research question, we chose to focus on a territory we will call ComCom. As an inter-municipality (or intercommunalité, a grouping of several municipalities with its own tax authority and specific prerogatives), ComCom consists of 15 municipalities (13 at the time of its creation, 15 since 2013), centred around an urban center. It is situated in the South of France, lies between two major urban areas, half of its territory being classified as part of the west-bound urban area (INSEE $1999-2010^{2}$ ). As such, ComCom is a typical periurban territory: at 2.51\%, its average annual growth rate $(1999-2005)$ is one of the highest in the country (INSEE), mostly due to the influx of new inhabitants coming from the main urban areas. To host these new inhabitants, municipalities have been building new houses and infrastructures, which in turn has led to the decrease (dramatic in some municipalities) of agricultural land. Aside from this shift in landscape, a shift in population dynamics causes tensions between old and new inhabitants and more specifically between farming activities and urban ones. The territory of ComCom is very diverse, both in urbanisation (contrast of very urbanised cities and rural small towns) and type of agriculture, with a high production of wine in the north, market gardening in the centre and livestock farming (bull, horse) in the south. However, the entire territory used to be dedicated to the production of wine (lowquality) before the wine production crisis $(1975$ - 1990) and a wine-growers' cooperative in the south used to be the most productive cooperative in Europe.

As an institution, ComCom was created in 1993 and originally existed for the sole purpose of sharing costs for wastewater treatment and garbage collection. It gradually gained more and more prerogatives, now being responsible for economic development, cultural and social policies, public transportation, etc. ComCom is led by a council of 46 members, all elected officials of one of the 15 municipalities, in a proportion agreed upon by the statutes. All municipalities must be represented by at least one member and no municipality can hold a majority of seats. The council elects the board, which consists of a president and 12 vicepresidents (to represent the 13 original municipalities), most of whom are also mayor of their municipalities. Elections are held after every municipal election.

In 2002, the council of ComCom decided to create its own SCOT, which was not yet mandatory but strongly suggested. At the time very few inter-municipalities had created one, let alone started the process, and very little documentation on how to proceed had been written beyond official legislation. Moreover, it was the first time the council members and ComCom employees had to work together on such a scale. The SCOT was approved by vote of the council and officially published in 2006.

\footnotetext{
${ }^{2}$ The INSEE is the French national institute for data collection and statistical analysis
} 
More than ten years later, the council members now claim that the SCOT is the one document that defines their policy, both for ComCom and outside. Taking a stance against the region's rapid urbanisation, it is a promise for the territory to stay a "breathing space" between the two urban areas, a place of equilibrium between nature and city, and an agricultural haven. It is today designated as the point of origin for the ComCom's agricultural policy.

\section{Data collection and treatment}

To show how the SCOT created a situation of learning in the ComCom, we used the qualitative method because its purpose is not to measure a phenomenon (which the quantitative method allows) but to give sense to empirical data. Drawing from the study of a single case, the agricultural policy of ComCom, we studied the embedded case (Yin, 2009) of the elaboration process of the SCOT. In an abductive fashion, we first started with a preliminary study including the analysis of documents (internal documentations, official documents, previous research papers) and first round of exploratory semi-structured interviews (12 interviews), not only with employees of ComCom, but also farmers and other stakeholders in agriculture on the territory, which allowed us to gain a broad understanding of how the territory functions and to pinpoint the creation of the SCOT as a turning point in the territory's strategy related to agriculture.

Only when the SCOT was identified as a key element did we start to build our framework. To understand the process behind the creation of the SCOT, we conducted semi-structured interviews with 12 of the 13 members of the board of ComCom's council (the president and 11 vice-presidents, the last one not being available at the time). Our goal in these interviews was to first understand their view of the territory in the agricultural context, and the role they gave themselves as elected officials regarding their territory. We then asked them to retrace the making of the SCOT from 2002 to 2006 and to comment on the actions of ComCom regarding its agricultural policy today. These interviews, coupled with an analysis of other planning instruments, council meeting proceedings from 2002 to today, non-participatory observation of meetings, and local press articles related to the subject, allowed us to create a chronicle of the SCOT (Rey-Valette et al., 2009) and later related actions. This analysis then allowed us to focus on the learning processes behind the events, connecting shifts in instruments, actions and network composition with the interviewees' accounts of the facts. The transcripts of the interviews were then coded according to a pre-established analysis grid to sort the contents of the interviews into themes.

Analysis of the qualitative data was done using two methods. First we proceeded to analyse the sequence of events to create templates which allow making visible relationships between certain events (Dumez, 2013). We then coded the material (transcripts of interviews, documents, and press articles) in a multi-thematic fashion using RQDA ${ }^{3}$ (equivalent to Nvivo). These themes came from general theories we used but also from the corpus itself, which allowed us to manage the risk of circularity in the coding process (Dumez, ibid.). We thus created a category labelled "learning" to identify elements within the corpus that were relevant to theories on organisational learning, with codes such as first_order and second_order; but we also created the category "SCOT", in which codes used to describe the process were grouped that came from the corpus, with codes such as "breathing_space" or "efficacy_of_SCOT". We then proceed to analyse resemblances and differences within the themes, to sort out the relationships that we analysed with the chosen theories, e.g. ANT.

\footnotetext{
${ }^{3}$ HUANG Ronggui (2014). RQDA: R-based Qualitative Data Analysis. R package version 0.2-7. http://rqda.rforge.r-project.org/
} 


\section{The "management situation"}

The frontiers of the dispositif itself are sometimes too blurred to use it to scientifically limit the research object. Some use the concept of project to name the situation in which these dispositifs intervene. However not all situations are relevant to the idea of project. So the adequate research object seems to be more in the vein of what Girin (1990) calls the "management situation" ("situation de gestion"), moments in the life of an organization. To Girin, "a management situation is considered as such when the participants are united and must accomplish, in a determined time, a collective action leading to a result submitted to an external evaluation." The management situation is a fitting framework in our case to study the creation of ComCom's SCOT. It is precisely a "moment" in the life of the territory, with a beginning and end, enrolled participants that do not necessarily encompass the whole territory, and the result of which, a written document in three parts, is submitted to evaluation or judgment both by other scales of territory (département, region) and by the members of ComCom. Moreover, all management situations have a territorial dimension since they are defined by three components: stakeholders, time (beginning and end), and space (RauletCroset, 2008). The territory is then both decisive to the situation (as an administrative territory, its entirety is taken into account in the situation) and to the stakeholders (as the inhabited territory, stakeholders take part in the management situation because they are part of this territory).

\section{RESULTS}

We will in this section recount the events from the first time the idea of a SCOT was presented to the many projects that were created after the SCOT was approved. However, to be able to separate events that happened during the making of the SCOT from events that result from it, we will define the management situation as follows.

The management situation begins on the 20th of December in 2001, which is when the procedure to create a SCOT was officially engaged. It ends on the 11th of July in 2006, when the board approved (through a vote) the written documents of the SCOT. The spatial dimension of the management situation was officially determined on the 24th of July in 2002, when the prefect agreed on the area of land to be included in the SCOT (which matches the perimeter of the Community of Communes) ${ }^{4}$. This spatial dimension partially defines the stakeholders associated with the situation: all 13 municipalities are involved, and the Community of Communes as a whole. As such, ComCom is in charge of elaborating the SCOT, all municipalities being represented through the bureau. Other stakeholders emerge during the management situation through participative processes (farmers, citizens, etc.), but they do not have any decision-taking power concerning the situation (they do not "manage" it). As such, we will represent them as being outside the situation.

\section{Building a governance network: enrolment and intermediaries.}

As the management situation revolves around the acceptation of an instrument or managerial innovation, we have analysed, following the actor-network theory, the processes of problematisation and enrolment that took place. The employees and elected officials have little experience when it comes to the new modes of governance - and their instruments necessary to the construction of a Community of Communes. The network is thus built mostly during the management situation, around the SCOT, which will become, through the

\footnotetext{
${ }^{4}$ It is important to note that there can be participants of the management situation that do not come from the territory, like consultants mandated by the territory for example. However, in the interest of simplification (and because we do not discuss the role of these consultants in this paper), we will consider that all participants come from the territory.
} 
translation process, an obligatory point of passage: it is viewed as unavoidable. The early problematisation allowed the definition of the stakeholders included in the management situation but also their relationships and strategies, and enabled the delimitation of the limits of the situation.

When the employees and elected officials of ComCom first get the idea of establishing a SCOT in 2001, many elected officials question the usefulness of the instrument, as it seems to be overlapping with already existing instruments relating to urbanisation (Local Urban Plans). It is first seen as a waste of means and time, and even more so as a menace, as it would appear to take away the elected officials prerogative as mayors to shape the urbanisation of their municipalities. As it is, the urbanisation practices largely differed from one municipality to another at the time in the territory, which was felt by the employees as another obstacle:

"It was a big obstacle at first: some mayors had in the past decade developed urbanisation practices that were in contradiction with one another... So it was difficult for them to accept other mayors looking at what they'd done and judging them on it. " ${ }^{5}$

This discrepancy between old practices and new land use rules created a series of controversies. They first appear during the problematisation stage, when the perimeter of the SCOT has to be determined - which also fixes the network in space. Many elected officials first wish to create a SCOT with an east-neighboring territory (département), on the other side of the river. The project is submitted for review to the west-neighboring major Metropolitan city, the département, and the Region. According to Emp $2^{6}$, the Region gave a positive review to the idea, while both the département and the Metro city gave a negative one. The prefect followed the opinion of the département when common practices dictate it should have sided with the Region. It then asked the ComCom to change the perimeter "because of existing uncertainty concerning the situation both west and east from ComCom". The board thus chooses to follow to same perimeter as that of the ComCom which El4 and El2 vote against to mark their disagreement with the prefect's decision. This controversy will later be re-interpreted by one of the elected officials, who will accuse the board of having chosen a perimeter that did not include the east-neighboring municipalities on the other side of the river!

As a "non-human stakeholder", the SCOT requires human mediators to include it within the network. The president of ComCom (El5), the vice-president officially in charge of the SCOT (El8) and a newly-elected mayor (El4) play this role of mediator, and will try to interest then enroll other stakeholders in the management situation. They first rally two employees: the director of ComCom (Emp2) and the project leader specifically recruited for the management situation, from 2003 to 2006 (Emp1). These two will draw up interessement devices and alliances to enroll others in the process. First, a lawyer specializing in urbanization practices and tools is invited to present to the board members the limits of local urban plans when it comes to creating a territorial project for development. Then, the project leader conducts interviews with each board member, but also with other elected official of the municipalities, to discuss with them their perception of the territory's identity. Collective discussions are organized around aerial shots of different parts of the territory, which highlight the reality of the territory's urbanization (urbanized areas vs. agricultural areas vs. wilderness or wasteland). As such, these shots represent true tokens, as they simplify the complexity of the

\footnotetext{
${ }^{5}$ The quotes are from abstracts of interviews of actors, done between 2013 and 2014, that have been translated from French to English by the authors of this paper.

${ }^{6}$ Name of elected officials and their municipalities have been respectively replaced with "El1" to "ElX", and

"Mun1” to “MunX”. Employees are named “Emp1”, “Emp2” or through their role (“project leader”).
} 
territory to allow discussion and progress. This discussion in turn shapes the construction, between the board members, of a shared definition of the territory, which is seen as a "breathing space” or "green lung” between two large metropolitan areas.

Other actions are set up to officially "launch" the consultation process with the inhabitants, which is a mandatory part of the process. Most notably, a survey concerning both farming and consumer practices is conducted. The consultation tools are specifically chosen by the project leader to avoid contact - and thus possible confrontation - between the inhabitants and the board members, which could "scare away" the board members that aren't yet fully enrolled in the situation. The consultation process is thus organized around a contest, through which the inhabitants are asked to take photos that represent the territory in their eyes. The use of intermediaries is thus frequent, both as human and non-human actors, between elected officials and inhabitants. For example, El7, who was first opposed to the idea of the SCOT, "let himself" be convinced, through these tools, to the idea of a collective production of common identity, even though he was the mayor of the most urbanized town within ComCom, and as such was very different from the majority of small, rural municipalities. The first survey in 2003, which received over a 1,000 answers, showed that the idea of a "breathing space" was also something shared with the inhabitants. The survey was then a strong argument to convince him: if he could legitimately argue against other elected officials, he couldn't go against the opinion of the inhabitants who had elected him:

"[El7] sensed that he couldn't do anything other than to agree with the idea of breathing space, because when he sensed it when he saw the result of the survey. The real, big effect was the 1,000 response we'd received".

Other tools were used to consolidate the enrolment of some board members: an exhibit was organized to display the results of the photo contest, which also played its part in "convincing" or at least reassuring the board members:

"A lot of them had taken pictures which represented the expansion of urban spaces. So it really helped the elected officials share a common sense of the territory".

At the end of the process, most elected officials were less vocal in their refusal to take part in the SCOT. Some were even enrolled, and joined the original mediators. The creation of the SCOT kept going, and a consulting firm was hired to help with the technical aspects. After two public meetings, the ComCom organized a "citizen council", made of volunteer inhabitants. It would meet five times during the process. Again, the employees would play the role of intermediary and translator, bringing back the conclusions of the council to the board members and avoiding any direct confrontation between elected officials and inhabitants.

As meetings of the sort accelerate (council meetings, board meetings, public meetings), the true shift in pace comes not from this process but from incidents external to the management situation. First, a succession of floodings from the nearby river force the elected official to take action and a plan is put into place to consolidate the riverbank, which concerns Mun6, Mun7 and Mun8. Major conflicts arise between El8 (in charge of the SCOT), and El6 and El7. These conflicts will have repercussion within the management situation, as El6 and El7 become a big opposition within the debates. During the same period, the mayor of the neighboring metropolitan city declares publicly his wish to create a "megalopolis" to join the two Metropolitan areas between which lays ComCom. This declaration, which is made without consultation with the board members of ComCom, creates strong opposing reactions, notably in the press. 
This controversy marks the end of the enrolment process, as it modifies and solidifies alliances, both within and outside of the management situation. The board members become unified in front of the mayor of the neighboring metropolitan city, at least in appearance, and they imagine the SCOT as an apparatus which can be used as a political statement: it isn't a simple managerial innovation, but becomes a dispositif (as defined by Foucault) which embodies the notion of "breathing space", i.e. protection of natural spaces (both green and agricultural). At the same time, the agricultural policy of ComCom takes shape, with the creation of a steering committee, new surveys to farmers and consumers, a task force on short food supply chains, etc. The SCOT as a political dispositive allows the creation of a legitimate territorial strategy, and becomes the early step to a real territorial project.

The SCOT is written directly by the employees of ComCom. The process of creation is officially stopped in the January $19^{\text {th }}$, 2006 meeting, then submitted to be reviewed by institutional partners (département, Region, etc.). The final version of the SCOT is validated through a vote in the ComCom Council on July $11^{\text {th }}, 2006$.

\section{Governance learning through instruments}

The first important step in governance learning happens during the management situation. The board learns to create a shared mental model of how to define the territory and what it means to be an elected official of this territory. This process is enabled by a series of tools (meetings, photographs, etc.) that allow the discussion among the board members. We consider the employee in charge of the elaboration of the SCOT as the "driver," having recognized (according to her) the need for these exchanges. This form of learning is later reinforced during other meetings, and is symbolized by the terms "breathing space" or "green lung" that would later appear in the written documents of the SCOT. This process is similar to what Weick calls sensemaking which involves "turning circumstances into a situation that is comprehended explicitly in words and that serves as a springboard into action" (Weick et al., 2005). According to the authors, it is strongly linked to the process of identity construction, which is a property of sensemaking. In our case study, it is during a phase of uncertainty (with an administration asking board members to develop a common project) that they make sense of the situation by learning to say "this is who we are" in a collective voice. This identity construction is then followed by the process of sensemaking that we can translate to the affirmation of "this is where we are". But we also identified this process as sensemaking because it is the moment the board members defined "this is why we are here together."

\section{Figure 1}

This learning process thus produced new knowledge since it was the first experience in terms of reflecting collectively on the territorial identity. This process is first collectively produced, and can be classified as second-order learning, since it is co-created by elected officials. It is set off by tools used by the project managers, mostly the final meeting discussing the aerial shots:

"As soon as we talked about the idea of what their municipality was like compared to [the neighbouring urban area], they immediately had the will to distinguish themselves, to position themselves differently. Each time, the rural and village identity came back"

Learning to build a collective identity, a common sense, is what allowed the members of the management situation to move forward. The effect of this learning process is the creation of a feeling of cohesion and coherence in the choice of the territory, when this was precisely subject to controversy in the early stages of the management situation: 
"We did a seminar and when we talked about our visions of the territory, we all answered the same way. So when you ignore everything else, we found an agreement. This is the meeting that allowed us to move forward. After that, the hardest was just small details, but on the vision we were all in agreement".

This learning process is also limited. If sensemaking drives the action forward, this action is bounded by legitimacy issues within the organisation. In the case of ComCom, this legimitacy comes from the competencies that have been delegated to ComCom by the municipalities composing it. The produced sense is thus limited to these competencies, and does not produce within the territory a will or a drive to act beyond this frame:

"For now everybody's working on their own; everybody's doing their own policy - which can be the same - but there's no cross-municipality action which would allow us to think collectively how this sector should be organised, how we can organise ourselves when the new railway is constructed, etc. I think we don't have a long-term plan. Well I think: I'm certain of it".

Another form of learning produced in the management situation and which also gives weight to the idea of "breathing space" is the transformation of the SCOT from a "common" managerial innovation to a political dispositif. The SCOT goes from being an instrument, which objective is to render urbanisation practices uniform within a territory, to a dispositif mobilised against the neighbouring metro area's development model. This process reflects the moment when individuals "seize" the innovation, or instrument, to transform its role within the organisation. We thus named this process instrument-seizing. In the same manner as sensemaking, it is collective learning co-produced by the elected officials members of the management situation. It represents both cognitive change (the way in which the members take on the instruments within the management situation) and behavioural change (the way in which the members react within the management situation). It is set off by an external event, the declaration of the neighbouring metropolitan city's mayor:

"When they managed to share this position, which came with the will from [the neighbouring metropolitan city's mayor] to create a megalopolis, that's when everything started to take. They carried the project of the SCOT politically".

Another effect of instrument-seizing is the appearance in public areas of the term "breathing space”, which is then used in press articles but also in public speeches. Some elected official started at this time to use the expression to justify spending in projects for the agricultural policy. In short, the expression is created through the process of sensemaking but is only turned into a political project through instrument-seizing.

This process transforms the dynamics within ComCom, beyond the management situation. A broader reflexion regarding agricultural policies is started. The point is not to seize the instrument simply as a reaction to the neighbour's policies, but to use this changed innovation to create an alternative project:

"We knew what was at stake: limiting space consumption to be coherent with our ideal of a 'breathing space'. The goal was to find a different development logic with physical limitations, space consumption, and then... that's why there were different stages: the SCOT was the first, then the agricultural policy, and the policy to protect natural spaces".

Figure 2 
In seizing the SCOT, the board members and other participants of the management situation learned to integrate new aspects of governance into the way they functioned. When participative methods were only imposed by the State as a procedure of the SCOT, they learned to use this dialogue with citizens and farmers to fuel their reflection and build new strategies illustrating their common goal. The elements indicating that learning was effectively produced are found after the management situation: several new participatory processes were introduced after the SCOT was already approved, which means they didn't fall under an obligation from the State. The inclusion of other stakeholders into their process of policy-making wasn't just an obligatory device anymore, but an instrument to reach their goal. However, there are two significant limits to this form of learning. The first one is a limit in time: these new participatory groups were dissolved after a few years and no other group was ever formed. As such, the participatory governance shifted from a highly consultative one at the end of the SCOT (with instruments co-created by the various stakeholders) to one of mere "information" today: citizens only kept informed through ComCom's monthly magazine and farmers barely included in projects. As one of the board members told us: "the projects we undertake for the agriculture in the territory matter. But it comes from us, not the farmers. So it's complicated." The second limit concerns who is learning. Not all board members learned the importance of participation. In fact, one of the most invested members of the management situation, the "young new mayor," himself admitted that he never consults the citizens of his municipality because it "complicates his role" and that they can give their opinion in the ballot box at every election. Moreover, almost all the "legwork" in these situations of participatory governance comes from the employees. Reading the minutes of meetings, we discovered that board members were often timid in their approach, not wanting citizens and farmers to be included "too soon" or into situations that had too high stakes. As such, employees are used as intermediaries so that board members are never truly confronted with other stakeholders.

\section{The organisational myth: institutionalising learning}

This idea of the territory constituting a "breathing space" or "green lung" between the two urban areas are vectors for learning. They are typically what are called organisational myths: something that allows the members of an organisation to create an interpretation of their environment on which they can rely. Even if they are false, myths allow the coordination of the members, making discussion a possibility, which contributes to building a community (March, 1999). As such, we do not ask if calling the territory a breathing space or a green lung is a just representation of the truth. Each member of the board (and the other members of ComCom as well) have accepted it as a truth. We will also show in this section that each are interpreting this myth in their own way. If myths are central to collective action in private organization, they seem to matter even more in the context of governance. Other myths in this context can be the idea of participation, which is now sometimes applied to situations of governance that don't necessarily call for it.

As a written document, the SCOT is also the medium for sensegiving. Outside the management situation that was the elaboration of the SCOT, others have also adopted this view of the territory. More specifically, board members who were elected in 2008, two years after the management situation, almost systematically use the terms "breathing space" or "green lung" to describe their territory. The myth seems then to be the carrier of implicit knowledge, while the SCOT may carry explicit knowledge within its written documents. This process constitutes a transfer of knowledge (created during the sensemaking process) from the original board members to new ones, but also new employees of ComCom and other stakeholders. It is both enabled through dialogue between the board members (socialisation), and through the written documents of the SCOT and through other written documents relating 
to the action of ComCom (combination). This process is similar to the notion of sensegiving, a process through which leaders supply a "workable interpretation to those who would be affected by [their] action" (Gioia and Chittipeddi, 1991). In this instance, the transmission of the myth is then an example of sensegiving, in that it supplies new members with an explanation, a justification to the reasoning behind the SCOT, but also gives them ways to join the collective action without having to redefine its limits, i.e. without having to reproduce innovative sensemaking after each new local election. The myth enables learning to be more sustainable, or to become organisational, in that it isn't dependant on the individuals who produced the knowledge, but remains within the organisation (i.e. the territory) after they leave.

Other members of ComCom also took part in sensegiving. Employees and collaborators of ComCom in charge of the agricultural policy after the management situation also have to integrate values and concepts carried by the myth to frame their action. The notion of sensegiving is also self-evident here as the elected officials, responsible for creating the "managerial line" of ComCom, give the employees this "workable interpretation".

Figure 3

However, the new board members then proceed to a form of sensemaking of their own, understandably through a process of internalisation of the transferred knowledge. In making this idea their own, they translate, or give their own sense to, what this "breathing space" or "green lung" means to them. For example, when interrogated about the nature of their territory, most attributed the breathing space as a "garden," the agriculture being represented as the producer of an enjoyable landscape for its inhabitants. Only some would translate the green lung as a farming territory producing their food. This interpretation of the myth is very different with that presented within the official documents, most notably the SCOT itself.

This internalisation and interpretation of the myth also happens within the original members of the management situation. Most remarkably, the publication of the "territory's project" in 2013 presents the evolution of the myth from the idea of "protecting natural spaces" to "creating balance between urban and rural spaces":

"The territory's project was finally to re-integrate the reality of the field, say 'okay we're not only rural, we're also urban', and so it's not about rejecting the urban and urbanisation, but work with both to create harmonious development".

This evolution of the myth also follows a shift in discourse within the documents and with the elected officials, who go from a "strong" opposition to the neighbouring metro city, to a vision of "synergy". Other board members even go so far as questioning the validity of the myth when put in context with other more "urgent" territorial challenges:

"Since 2008, I remember before we talked about 'breathing space'. Now unemployment is widespread, and they talk about it less. So whenever they do, I tell them 'be careful!' So they talk about it less because it's $17 \%$ of unemployment”.

The organisational myth thus not only helps create an "interpretation of the environment", but acts as a vector to institutionalise learning, i.e. to turn collective learning into organisational learning. It helps new knowledge become more resilient, which in turn makes the territory more resilient, especially in periurban areas where individuals come and go. 


\section{CONCLUSION}

In this paper, we focused on a longitudinal case study, trying to understand how territorial governance can both be shaped by a territory, and how the territory is in return shaped by the evolution of governance. More specifically, we claimed that governance is something to be learned through experiences in collective action, or 'management situations'. We studied one such situation within which board members are asked for the first time, through the implementation of an instrument for public action, to cooperate and think about the strategic development of their territory. Through the analysis of a specific management situation, the adoption of a managerial innovation, and using theories of organizational learning applied to situations of territorial governance, we identified three main instances of learning: sensemaking, in which learning is centred on the board members; sensegiving, in which learning is centred on new board members, employees and other stakeholders who arrived after the management situation and later internalised the values; instrument seizing, in which board members turned the instrument into a dispositif, which allowed for a shift in the mode of governance.

Governance learning was thus enabled through the use of managerial innovations, stakeholders of the territory learning to share common values and define common goals to cooperate with each other, but also learning to reorganize into new networks and to extend their collaboration with new stakeholders. Applying Actor-Network Theory to the case study allowed us to demonstrated, through a behavioural approach, that governance processes are the result of power relations and exchanges both within the territory and outside of it: the structure of the network, the managerial instruments, and the decision-making process all depend on the relationships between the actors of the network, and how each reacts to the others. ANT also allowed us to demonstrate a critical aspect of governance learning: collective learning can appear to come from a consensus, but we showed that it actually comes from the controversies around it. What we couldn't develop in this article is the important notion that these controversies actually seem to help embed knowledge and give it more sense. Finally, we showed that myths are central to the diffusion and institutionalisation of rules and norms in governance. It becomes a new way of thinking, something that won't necessarily be questioned. In this sense, myths can also become instruments of power.

This research allows a better understanding of territorial governance, specifically how stakeholders can learn to cooperate through the use of instruments. Armitage et al. (2008) criticized much of the existing literature using learning theories instrumentally without exploring the "what, where, when and how" of learning processes involved in governance; we hope that this paper gives a more developed framework to explore those questions. The systematic reference to material innovations, tools and instruments for example can help demonstrate the complexity of the learning processes. We wish this research to also be useful to practitioners, especially territorial managers, to help them understand the behaviour of board members, and their relationship with managerial instruments. During our interviews, managers often reflected negatively on the experience of controversy between board members, thinking it was hindering the debate. What our research shows is that these moments actually enabled learning and drove the process forward.

However, we could only focus in this article on broad definitions of what constitutes learning. In reality, these three examples could be described in much more detail, especially concerning who really is learning. Indeed, behind these collective forms of learning exists an asymmetry on how learning is internalized by each member, how the knowledge produced can also change, and if these examples of governance learning are truly lasting. 


\section{BIBLIOGRAPHY}

Adger, W. N. (2010). Social Capital, Collective Action, and Adaptation to Climate Change. In M. Voss (Ed.), Der Klimawandel (pp. 327-345). VS Verlag für Sozialwissenschaften.

Aggeri, F., \& Hatchuel, A. (1997). Les instruments de l'apprentissage. Du Mode d'existence Des Outils de Gestion, J.C. Moisdon (dir), [instruments for learning. On the existence on management tools] 216-247.

Argyris, C., \& Schön, D. A. (1996). Organizational learning: Vol. 2. theory, method, and practice. Reading, MA: Addison-Wesley.

Armitage, D., Marschke, M., \& Plummer, R. (2008). Adaptive co-management and the paradox of learning. Global Environmental Change, 18(1), 86-98.

Berkes, F. (2009). Evolution of co-management: Role of knowledge generation, bridging organizations and social learning. Journal of Environmental Management, 90(5), 16921702.

Berrebi-Hoffmann, I., \& Boussard, V. (2005). Avant-propos. Sociologies Pratiques, [Foreword. Practical Sociology] 10(1), 1.

Bruges, M., \& Smith, W. (2007). Participatory approaches for sustainable agriculture: A contradiction in terms? Agriculture and Human Values, 25(1), 13-23.

Callon, M. (1986). Éléments pour une sociologie de la traduction: la domestication des coquilles Saint-Jacques et des marins-pêcheurs dans la baie de Saint-Brieuc. L'Année Sociologique (1940/1948-) [Elements for a sociology of translation : domestication of sea scallops and fishermen in the bay of Saint-Brieux. The year of sociology], 36, 169-208.

Callon, M., Lascoumes, P., \& Barthe, Y. (2001). Agir dans un monde incertain - Essai sur la démocratie technique. [Acting in an uncertain world - essays on technical democracy] Seuil.

Chia, E., \& Napoleone, M. (2008). «La coordination par l'apprentissage et la confiance: le cas d'une petite coopérative caprine en zone AOC pélardon» [Coordination through learning and trust : the case of a small cooperative in the Pélardon AOC region]. Communication au colloque «Les entreprises coopératives agricoles, mutations et perspectives», [Communication in the seminar « Farming cooperatives, mutations and perspectives] SFER, Paris (pp. 26-29).

Danet, A. (2010, Juin). Le SCOT : un nouvel instrument pour quelle action publique? (Mémoire de 4ième année d'I.E.P.) [The SCOT : a new instrument for which public action ? Master's dissertation]. Institut d'études politiques de Strasbourg, Université de Strasbourg.

David, A., Hatchuel, A., \& Laufer, R. (2001). Les nouvelles fondations des sciences de gestion. [The new foundations of management sciences]. Paris: Vuibert, 212 p.

Dieleman, H. (2013). Organizational learning for resilient cities, through realizing eco-cultural innovations. Journal of Cleaner Production, 50, 171-180.

Duguid, F., Mündel, K., \& Schugurensky, D. (2007). Volunteer work, informal learning, and the quest for sustainable communities in Canada. Canadian Journal for the Study of Adult Education, 20(2), 41-56.

Dumez, H. (2013). Méthodologie de la recherche qualitative: les 10 questions clés de la démarche compréhensive. [Methodology of qualitative research : ten key questions of the comprehensive approach] Paris: Vuibert, 240 p.

Gioia, D. A., \& Chittipeddi, K. (1991). Sensemaking and sensegiving in strategic change initiation. Strategic Management Journal, 12(6), 433-448. 
Girin, J. (1990). L'analyse empirique des situations de gestion: éléments de théorie et de méthode. [Empirical analysis of management situations : elements of theory and method] Epistémologies et Sciences de Gestion, Economica, 141-182.

Innes, J. E., \& Booher, D. E. (2003). Collaborative policymaking: governance through dialogue. In Deliberative policy analysis: Understanding governance in the network society (pp. 33-59).

Kimberly, J. R. (1981). Managerial innovation. Handbook of organizational design, 1(84), 104.

Lamari, M. (2011). Le transfert intergénérationnel des connaissances tacites. [Intergenerational transfer of tacit knowledge] In La Gouvernance. Frontières, dispositifs et agents (Presses de l’Université du Québec, pp. 397-433).

Lascoumes, P., \& Simard, L. (2011). L’action publique au prisme de ses instruments. [Public action through its instruments] Revue Française de Science Politique, 61(1), 5-22.

Leloup, F., Moyart, L., \& Pecqueur, B. (2005). La gouvernance territoriale comme nouveau mode de coordination territoriale? [Territorial governance as a new way for territorial coordination ?] Géographie, Économie, Société, 7(4), 321-332.

Le Roy F., Robert M., Guiliani Ph., 2013, 'L'innovation managériale’ Généalogie, défis et perspectives, [Managerial Innovation : Genealogy, challenges, perspectives] Revue française de gestion, 2013/6 N²35, p. 77-90.

March, J. G. (1999). Les mythes du management. [The myths of management] Annales de l'Ecole de Paris, 5. Retrieved from http://www.annales.org/edit/gc/1999/gc09-99/0412.pdf

Moisdon, J.-C. (2005). Comment apprend-on par les outils de gestion ? retour sur une doctrine d'usage. [How do we learn from managerial tools ?] In P. Lorino \& R. Teulier, Entre connaissance et organisation : l'activité collective (La Découverte).

Newig, J., Günther, D., \& Pahl-Wostl, C. (2010). Synapses in the network: learning in governance networks in the context of environmental management. Ecology and Society, 15(4), 24.

Nonaka, I., \& Takeuchi, H. (1995). The knowledge-creating company: How Japanese companies create the dynamics of innovation. Oxford University Press, USA. Retrieved from

Oiry, E. (2003). La construction des dispositifs de gestion : une analyse par le concept de traduction. [Constructing management dispositifs : an analysis through the concept of translation] In V. Boussard \& S. Maugeri, Du politique dans les organisations: sociologies des dispositifs de gestion. [Politics in organisations : sociology of management dispositifs] Editions L'Harmattan.

Örtenblad, A. (2001). On differences between organizational learning and learning organization. Learning Organization, The, 8(3), 125-133.

Perrin, C., Jarrige, F., \& Soulard, C.-T. (2013). L'espace et le temps des liens ville-agriculture: une présentation systémique du cas de Montpellier et sa région. [Space and Time in cityagriculture bonds : a systemic presentation of Montpellier and its region] Cahiers Agricultures, 22(6), 552-558.

Raulet-Croset, N. (2008). La dimension territoriale des situations de gestion. [The territorial dimension of management situation] Revue Française de Gestion, 34(184), 137-150.

Rey-Valette, H., Pinto, M., Maurel, P., Chia, E., Guihéneuf, P.-Y., Michel, L., ... Champigraud, A. (2011). Guide pour la mise en oeuvre de la gouvernance en appui au développement durable des territoires. [guide for the implementation of governance for sustainable development of territories] Cemagref, CNRS, Geyser, Inra, SupAgro, Université Montpellier 1. 
Rey-Valette, H., Soulard, C., Mathé, C., Michel, L., Jarrige, F., Maurel, P., ... Laurens, L. (2009). Gouvernance des territoires et développement rural: une grille d'analyse pour appréhender les innovations organisationnelles. [Governance of territories and rural development : an analytical tool to comprehend organisational innovations] Presented at the colloque de l'ASRDLF « Entre projets locaux et de développement et globalisation de l'économie: quels équilibres pour les espaces régionaux? »

Rousier, N., \& Bertrand, N. (2003). L'agriculture face au développement économique : un combat inégal ou des politiques périurbaines à construire [Agriculture versus economic development : an unequal fight or a question of new policies for the peri-urban area]. Revue de Géographie Alpine, 91(4), 93-103.

Senge, P. (2006). The fifth discipline: The art and practice of the learning organization (2nd ed.). Random House Business.

Sol, J., Beers, P. J., \& Wals, A. E. J. (2013). Social learning in regional innovation networks: trust, commitment and reframing as emergent properties of interaction. Journal of Cleaner Production, 49, 35-43.

Soulard, C., \& Thareau, B. (2009). Les exploitations agricoles périurbaines : diversité et logiques de développement. [Periurban farms : diversity in logic and development] Innovations Agronomiques, (5), p.27-40.

Torre, A., Aznar, O., Bonin, M., Caron, A., Chia, E., Galman, M., ... Kirat, T. (2006). Conflits et tensions autour des usages de l'espace dans les territoires ruraux et périurbains. Le cas de six zones géographiques françaises. [Conflicts and tensions around space uses in periurban and rural territories. The case of six geographic French zones] Revue d'Économie Régionale \& Urbaine, août(3), 415.

Van Assche, K., Beunen, R., Holm, J., \& Lo, M. (2013). Social learning and innovation. Ice fishing communities on Lake Mille Lacs. Land Use Policy, 34, 233-242.

Weick, K. E. (1990). Cartographic myths in organizations. In Mapping strategic thought (John Wiley \& Sons, pp. 1-10). A.S. Huff.

Weick, K. E., Sutcliffe, K. M., \& Obstfeld, D. (2005). Organizing and the process of sensemaking. Organization Science, 16(4), 409-421.

Yin, R. K. (2009). Case study research: Design and methods (Vol. 5). Sage.

Young, R. F. (2010). The greening of Chicago: environmental leaders and organisational learning in the transition toward a sustainable metropolitan region. Journal of Environmental Planning and Management, 53(8), 1051-1068.

\section{ACKNOWLEDGEMENTS}

This work was supported by the French National Agency for Research under grant 'ANR DAUME-2010-STRA-007-01'; by CIRAD under their incentive action program; and by ECOS-CONICYT under grant 'C12H02'.

\section{FIGURES}




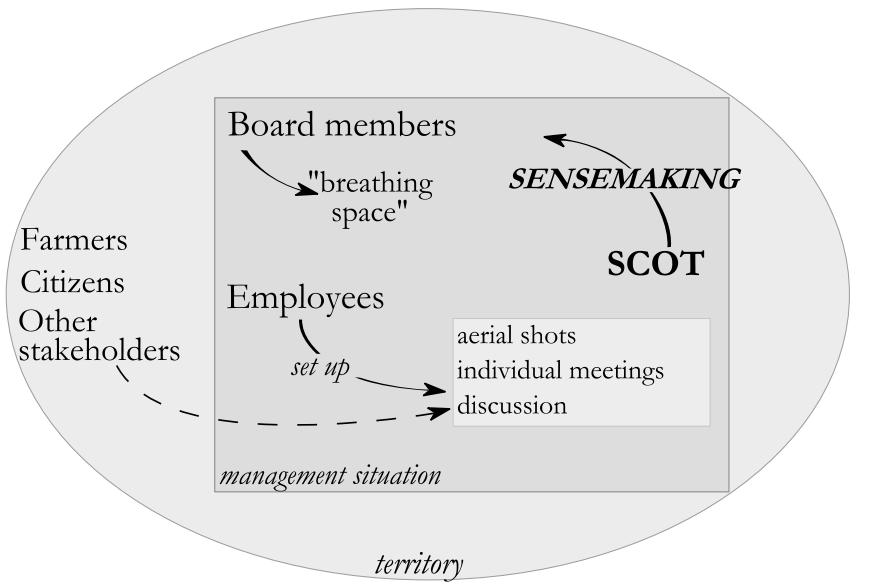

Figure 1: sensemaking

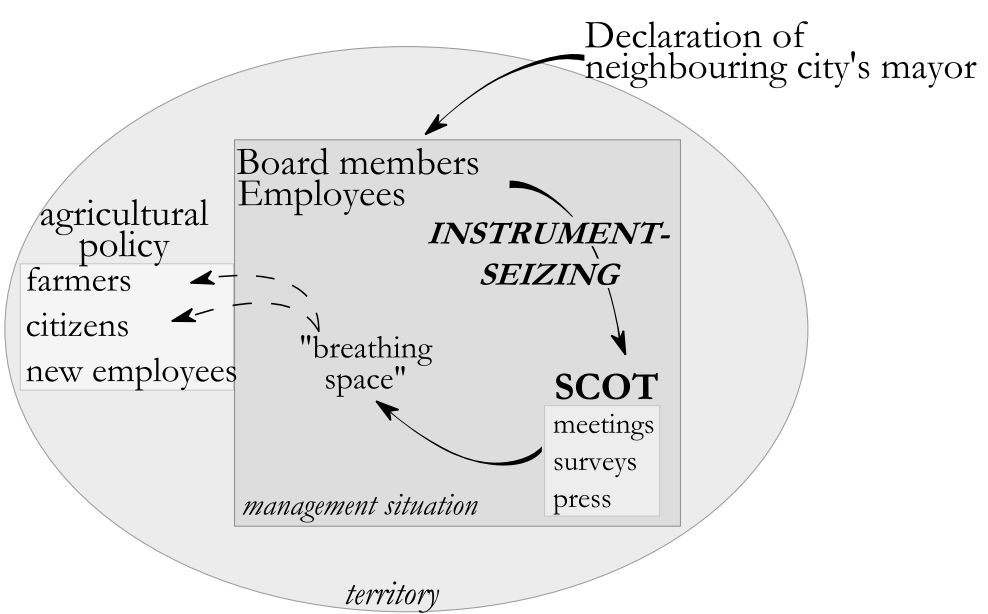

Figure 2: instrument seizing

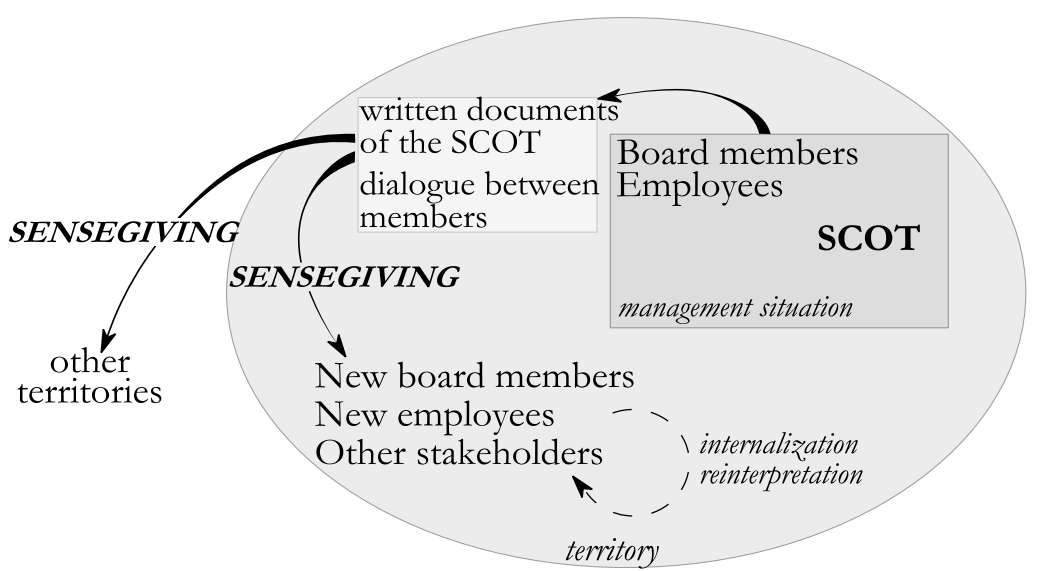

Figure 3: sensegiving 